\title{
Pepsinogen-II 100 bp ins/del gene polymorphism and its elevated circulating levels are associated with gastric cancer, particularly with Helicobacter pylori infection and intestinal metaplasia
}

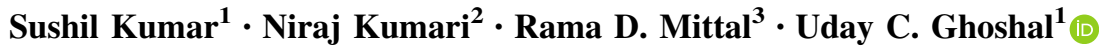

Received: 27 October 2014/ Accepted: 22 September 2015/Published online: 20 October 2015

(c) The International Gastric Cancer Association and The Japanese Gastric Cancer Association 2015

\begin{abstract}
Background Polymorphism in the gene of pepsinogen-II (PG-II) and its serum level are effective biomarkers for terminal differentiation of gastric mucosa into gastritis, intestinal metaplasia (IM), and gastric cancer (GC) in relationship to Helicobacter pylori infection.

Methods Genotyping of the PG-II $100 \mathrm{bp}$ insertion/deletion (ins/del) polymorphism was performed in patients with GC $(n=192)$ and age- and gender-matched H. pylori-associated dyspepsia $(n=180)$ and healthy subjects (HS, $n=240$ ) by PCR. IgG anti-H. pylori (in all subjects) and serum PG-II levels were estimated in 145 patients each with GC and dyspepsia and in 65 healthy controls (HC) using ELISA (Biohit Oyj, Finland).

Results Five alleles were amplified by PCR: allele 5 (510 bp), allele 4 (480 bp), allele 3 (450 bp), allele 2 (400 bp), and allele 1 (shorter allele, $310 \mathrm{bp}$ ). Allele 1 carriage was infrequent, and serum PG-II level was higher among patients with GC than in HC [OR 0.43 (95\% CI, $0.29-0.85), p<0.001$ and mean $\pm \mathrm{SD} ; 17.53 \pm 12.60$ vs. $12.77 \pm 7.53 \mu \mathrm{g} / \mathrm{l}, p=0.005$, respectively], particularly in the presence of $H$. pylori [OR $0.42(0.25-0.71), p=0.001$ and $18.78 \pm 12.63$ vs. $13.97 \pm 8.14, p=0.034]$. However, allele 1 carriage and PG-II levels were comparable among
\end{abstract}

Uday C. Ghoshal

udayghoshal@gmail.com

1 Department of Gastroenterology, Sanjay Gandhi Postgraduate Institute of Medical Sciences, Lucknow 226014, India

2 Department of Pathology, Sanjay Gandhi Postgraduate Institute of Medical Sciences, Lucknow 226014, India

3 Department of Urology, Sanjay Gandhi Postgraduate Institute of Medical Sciences, Lucknow 226014, India patients with GC and dyspepsia. Patients with IM also carried allele 1 infrequently and had higher levels of PG-II than those without [OR $0.5 \quad(0.29-0.85), p=0.011$ and $20.07 \pm 14.22$ vs. $16.61 \pm 12.08, p=0.048]$.

Conclusions Carriage of the shorter allele of the PG-II $100 \mathrm{bp}$ ins/del polymorphism and elevated levels of PG-II are associated with GC, particularly with $H$. pylori infection and IM.

Keywords Pepsinogen II polymorphism - Intestinal metaplasia $\cdot$ Helicobacter pylori $\cdot$ Dyspepsia $\cdot$ Gastritis

\section{Introduction}

Although the prevalence of gastric cancer (GC) has recently declined, it is still the second leading cause of cancer-related deaths worldwide, as well as in India among men $(12.6 \%)$ and women $(14.1 \%)$ [1, 2]. GC develops through multiple histological steps such as chronic gastritis, gastric atrophy, intestinal metaplasia (IM), and dysplasia [3]. The three major etiological factors for development of GC are Helicobacter pylori infection, genetic susceptibility, and dietary factors. Recently, several host genetic polymorphisms have been regarded as potential factors contributing to development of GC.

The human pepsinogen (PG)-II (or C) gene is located in the $6 \mathrm{p} 11-6 \mathrm{p} 21.3$ region of chromosome 6 and contains a 100-bp insertion/deletion (ins/del) polymorphism between exons 7 and $8[4,5]$. This polymorphism has emerged in recent years as an important determinant of disease susceptibility and severity [6-8]. Different allelic forms of PG-II gene polymorphism may alter its serum levels, and the changes in PG-II levels are associated with several gastric diseases such as gastritis, peptic ulcer, and GC. Studies on the 
association between PG-II gene polymorphism and GC are scant. In this study, we aimed to evaluate the biological role of PG-II gene polymorphism in the development of precancerous gastric lesions and GC.

Circulating PG-II is a proenzyme of pepsin II, an endoproteinase present in gastric juice. It is secreted predominantly by pyloric glands in the gastric mucosa and the proximal duodenal mucosa $[9,10]$. The circulating levels of PG-II may be helpful for noninvasive assessment of atrophic gastritis (AG), which predicts the occurrence of GC $[11,12]$. AG is also frequently associated with IM, another precursor of GC, in contrast to nonatrophic gastritis [13, 14]. An elevated level of circulating PG-II is a marker of AG, and it remains high even in the presence of gastric ulcer $[15,16]$. Therefore, serum PG-II levels may be used as a noninvasive biomarker of AG and IM [17]. H. pylori infection is a known factor, influencing interindividual variation in PG-II levels and the risk of GC $[18,19]$. Because patients with dyspepsia are often associated with $H$. pylori infection and yet do not develop GC, we wanted to compare PG-II gene polymorphism with their serum levels as compared to patients with GC [20, 21]. Accordingly, we designed this case-control prospective study to evaluate the association between the PG-II $100 \mathrm{bp}$ ins/del gene polymorphism, its circulating level among patients with GC and dyspepsia and in healthy controls (HC) in relationship to histological findings and $H$. pylori infection.

\section{Methods}

\section{Study subjects}

Two hundred patients with non-cardia GC were included in this study. One hundred eighty-two age- and gender-matched H. pylori-associated patients with dyspepsia were included as controls on the basis of endoscopy and Rome III criteria [22]. Subjects who had received antimicrobial therapy, $\mathrm{H}_{2^{-}}$ receptor blockers, proton-pump inhibitors, and nonsteroidal antiinflammatory drugs within 15 days previously were excluded from the study. Two hundred and fifty volunteers from the community (age- and gender matched) willing to participate in the study were included as HC. Patients and controls were of similar ethnicity. The study protocol was approved by the Institutional Ethics Committee, and written informed consent was obtained from all the subjects.

Demographic and clinical parameters were recorded using a standard questionnaire. Data on smoking (in form of bidi, hukka, or cigarettes) and tobacco chewing (in the form of surti, paan with surti, and gutka) were recorded from all the subjects. The frequency and quantity of alcohol consumption were also recorded.

\section{Sample collection}

Six biopsies were collected in $10 \%$ neutral buffered formalin from tumor margins during upper gastrointestinal endoscopy (Olympus Optical, Tokyo, Japan), and sections were evaluated after hematoxylin and eosin (H\&E) staining to confirm the presence and subtype (Lauren) of malignancy [23]. Four biopsies were obtained from patients with $\mathrm{GC}$ (gastric mucosa away from the tumor) and dyspepsia (two each from antrum and body) for evaluation of IM, gastritis, and H. pylori infection. IM and gastritis (graded according to the updated Sydney system) were assessed by an expert pathologist, who was blinded about the other parameters [24, 25].

A 2-ml blood sample was collected from all the patients and controls in ethylenediaminetetraacetic acid (EDTA) vacutainer tubes for genotyping. A 2-ml blood sample was also collected in gel clot activator-based vacutainers (RS Biosciences, USA), after $8-10 \mathrm{~h}$ of fasting, for estimation of PG-II level.

\section{Diagnosis of $H$. pylori infection}

H. pylori infection was diagnosed by an enzyme-linked immunosorbent assay (ELISA), rapid urease test (RUT), and histopathology. Anti-H. pylori $\operatorname{IgG}$ antibodies were tested by ELISA using a commercially available kit (Biohit Oyj, Finland) as per manufacturer's instructions on sera obtained from patients as well as controls [26]. A cutoff value of antibody concentration $\geq 30$ enzyme immune units (EIU) was considered positive. RUT was performed using an in-house method, the sensitivity and specificity of which have been validated previously [27]. A change in color from yellow to pink during a 2 -h observation period was considered as a positive test. Sections from biopsies stained with hematoxylin and eosin and Giemsa stain were used for diagnosis of $H$. pylori by histopathology.

\section{DNA extraction and genotyping of pepsinogen-II 100 bp ins/del polymorphism}

Genomic DNA was extracted from peripheral blood leukocytes using a commercially available kit with slight modifications (AuPrep, Life Technologies, New Delhi, India). The ratio of absorbance at 260 and $280 \mathrm{~nm}$ of isolated DNA was around $1.65-1.92$ and stored at $-40{ }^{\circ} \mathrm{C}$ until use. Genotyping was done by polymerase chain reaction (PCR), which amplifies the DNA in the intron between exons 7 and 8 by these primers: forward PGCa:5' AGCCCTAAGCCTCTTTTTGG- $3^{\prime}$ and reverse PGCb:5'GGCCAGATCTGCGTGTTTTA- $3^{\prime}$. The PCR reaction was performed according to the previously published protocol [5]. Band size of PCR products was resolved by $3 \%$ agarose gel electrophoresis. 


\section{Estimation of serum PG-II level}

Serum PG-II levels were estimated in 145 patients with GC, 145 patients with dyspepsia, and $65 \mathrm{HC}$ using a commercially available ELISA kit (Biohit Oyj, Finland) as per manufacturer's instructions. PG-II levels were expressed in microgram per liter. The standard curve was plotted to calculate final concentrations and results [26].

\section{Statistical analysis}

Chi-square $\left(\chi^{2}\right)$ test was used for comparison of categorical data. Patients were categorized on the basis of disease group, presence or absence of IM, gastritis, serological test for H. pylori, and Lauren's classification of GC. Binary logistic regression was used to estimate risks as odds ratio (OR) with $95 \%$ confidence intervals (CI) using software SPSS 15 (SPSS, Chicago, IL, USA). Differences between serum PG-II levels were analyzed using independent $t$ test. Bonferroni's correction (a multiple comparison correction) was applied to significant associations.

\section{Results}

\section{Demographic parameters}

Age and gender were comparable among patients with GC and HC. Similarly, gender was also comparable but age was dissimilar among patients with GC and dyspepsia (Table 1). Tobacco habits and alcoholism were also similar among all the groups (Table 1).

\section{Histological parameters}

Patients with GC had higher frequency of IM than those with dyspepsia [64/178 (36.0\%) vs. 16/179 (8.9\%), $p<0.001]$ but similar frequency of gastritis [115/176 $(65.3 \%)$ vs. $131 / 175(74.9 \%), p=n s]$. Severity of gastritis (mild, moderate, and severe) was similar among patients with GC and dyspepsia (Table 1). By Lauren's classification of GC $(n=176), 92(52 \%)$ had intestinal and $75(43 \%)$ had a diffuse type of tumor. In 9 patients $(5 \%)$, the tumor was unclassified.

\section{H. pylori infection}

Biopsy-based tests such as RUT and histology represent the active infection whereas serum-based anti-H. pylori $\mathrm{IgG}$ antibody ELISA might represent infection in the past. Data on evaluation of $H$. pylori infection according to a standard protocol using three tests are presented in Table 1. These data show that biopsy-based tests such as histology and RUT less often detected $H$. pylori infection than serology. Because endoscopy-based tests (RUT and histology) were not ethically permitted among HC, we undertook only serology-based tests among these controls. Anti-H. pylori IgG ELISA was comparable among patients and controls (Table 1). To avoid the discrepancy in $H$. pylori diagnosis, we have used only anti-H. pylori IgG ELISA test results for comparison of gene polymorphism and serum levels.

\section{Genotype frequency of PG-II 100 bp ins/del polymorphism among patients and controls}

PCR product was absent in 8 patients with GC, 2 with dyspepsia, and 10 with HC. Distribution of genotypes among 192 patients with GC compared to 180 patients with dyspepsia and $240 \mathrm{HC}$ is shown in Table 2. Frequency of genotype 4/3 (480/450 bp) and 4/2 (480/400) was more frequent among patients with GC than HC [40/192 (20.8\%) vs. $32 / 240(13.3 \%), p=0.038$ and $21 / 192(10.9 \%)$ vs. $12 / 240(5 \%), p=0.021$, respectively]. However, genotype $1 / 1$ (310/310 bp) was infrequent among patients with GC than dyspepsia and HC [16/192 (8.3\%) vs. 36/180 (20\%) and $45 / 240$ (18.7), $p$ value 0.001 and 0.002 , respectively].

\section{Allele frequency of PG-II gene polymorphism among patients and controls}

The carriage of allele 1 is important in PG-II $100 \mathrm{bp}$ ins/del gene polymorphism and risk of GC [6,7]. Five alleles were amplified by PCR: allele 5 (510 bp), allele 4 (480 bp), allele 3 (450 bp), allele 2 (400 bp), and allele 1 (310 bp; shorter allele). Allele 1 carriage was infrequent among patients with GC compared to HC [82/192 (42.7\%) vs. 153 $(63.8 \%), p<0.001$, OR $0.43(0.29-0.85)]$. Carriage of allele 1 also tended to be lower among patients with GC than dyspepsia (Table 3).

\section{Association between allele 1 carriage and histological findings}

Frequency of allele 1 carriage was comparable among intestinal type compared with the diffuse type of GC (Table 3). Distribution of allele 1 carriage and non-carriage was also similar among patients with gastritis and among patients with different degrees of gastritis (Table 3). Patients with IM (GC and dyspepsia both) had more infrequent allele 1 carriage than those without [27/79 $(34.2 \%)$ vs. $130 / 265 \quad(49.1 \%) ; \quad$ OR $0.5 \quad(95 \%$ CI $0.29-0.85), p=0.011]$.

In case-only analysis, the frequency of allele 1 carriage was similar among patients with GC and dyspepsia in the 
Table 1 Demographic data, histology, Helicobacter pylori, tobacco habits, and alcoholism among patients and controls

\begin{tabular}{|c|c|c|c|c|}
\hline & $\mathrm{GC}(n=192)$ & $\mathrm{DC}(n=180)$ & $\mathrm{HC}(n=240)$ & $p$ value \\
\hline Age in years $($ mean \pm SD) & $52.91 \pm 12.35$ & $49.31 \pm 9.63$ & $51.46 \pm 10.45$ & $\begin{array}{l}\mathrm{GC} \text { vs. } \mathrm{DC}=\mathbf{0 . 0 0 2} \\
\mathrm{GC} \text { vs. } \mathrm{HC}=0.187\end{array}$ \\
\hline Gender (male) & $136(70.8 \%)$ & $116(64.4 \%)$ & $168(70.0 \%)$ & $\begin{array}{l}\mathrm{GC} \text { vs. } \mathrm{DC}=0.188 \\
\mathrm{GC} \text { vs. } \mathrm{HC}=0.850\end{array}$ \\
\hline \multicolumn{5}{|l|}{ Tobacco habits $^{\mathrm{a}}$} \\
\hline Chewing of surti, paan with surti, and gutka & $65 / 185(35.1 \%)$ & $56 / 178(31.5)$ & $52 / 215(24.2 \%)$ & NS \\
\hline Smoking & $47 / 187(25.2 \%)$ & $62 / 179(34.6 \%)$ & $48 / 208(23.1 \%)$ & NS \\
\hline Both chewing and smoking & $37 / 185(20 \%)$ & $33 / 178(18.5 \%)$ & $29 / 210(13.8 \%)$ & NS \\
\hline No tobacco use & 75/187 (40.1\%) & $61 / 179(34.1 \%)$ & $115 / 215(53.5 \%)$ & NS \\
\hline \multicolumn{5}{|l|}{ Alcoholism $^{\mathrm{a}}$} \\
\hline Alcoholic & $56 / 192(29.2 \%)$ & $52 / 180(28.9 \%)$ & $35 / 192(18.2 \%)$ & NS \\
\hline Non-alcoholic & $136 / 193(70.8 \%)$ & $128 / 180(71.1 \%)$ & $157 / 192(81.8)$ & NS \\
\hline \multicolumn{5}{|l|}{ Helicobacter pylori infection } \\
\hline IgG ELISA & $100 / 168(59.5 \%)$ & $120 / 180(66.7 \%)$ & $164 / 240(68.3 \%)$ & $\begin{array}{l}\mathrm{GC} \text { vs. } \mathrm{DC}=0.167 \\
\mathrm{GC} \text { vs. } \mathrm{HC}=0.067\end{array}$ \\
\hline RUT & $44 / 150(29.3 \%)$ & $64 / 154(41.6 \%)$ & & 0.026 \\
\hline Histopathology & $57 / 164(34.8 \%)$ & $115 / 182(63.2 \%)$ & & $<0.001$ \\
\hline \multicolumn{5}{|l|}{ Histological findings } \\
\hline Intestinal metaplasia & $64 / 178(36.0 \%)$ & $16 / 179(8.9 \%)$ & & $<0.001$ \\
\hline Gastritis & $115 / 176(65.3 \%)$ & $131 / 175(74.9 \%)$ & & 0.062 \\
\hline Severity of gastritis & $n=115$ & $n=131$ & & \\
\hline Mild & $85(73.9 \%)$ & $108(82.4 \%)$ & & 0.984 \\
\hline Moderate & $24(20.9 \%)$ & $20(15.3 \%)$ & & 0.797 \\
\hline Severe & $6(5.2 \%)$ & $3(2.3 \%)$ & & 0.749 \\
\hline \multicolumn{5}{|l|}{ Lauren classification of GC $(n=176)$} \\
\hline Diffuse & $75(42.6 \%)$ & & & \\
\hline Intestinal & $92(52.3 \%)$ & & & \\
\hline Unclassified & $9(5.1 \%)$ & & & \\
\hline
\end{tabular}

Bold values are significant $(p<0.05)$

$G C$ gastric cancer, $D C$ dyspepsia control, $H C$ healthy control, $S D$ standard deviation, $N S$ not significant, $I g G$ ELISA anti- $H$. pylori IgG enzymelinked immunosorbent assay, RUT rapid urease test

presence and absence of IM and gastritis [in case of IM: $\mathrm{IM}^{+} /$ $\mathrm{GC}^{+}: 24 / 64(37.5 \%)$ vs. $\mathrm{IM}^{+} /$dyspepsia $^{+}:$4/16 (25\%), $p=0.397$ and $\mathrm{IM}^{-} / \mathrm{GC}^{+}: 55 / 106(51.9 \%) \mathrm{vs}$. $\mathrm{IM}^{-} / \mathrm{dys}-$ pepsia $^{+}: 88 / 161(54.7 \%), p=0.707$ and in case of gastritis: gastritis ${ }^{+} / \mathrm{GC}^{+}: 51 / 109(46.8 \%)$ vs. gastritis ${ }^{+} /$dyspepsia $^{+}$: 67/129 (51.9\%), 0.438 and gastritis ${ }^{-} / \mathrm{GC}^{+}: 27 / 59(45.8 \%)$ vs. gastritis ${ }^{-} /$dyspepsia $^{+}:$24/44 (54.5\%), $\left.p=0.429\right]$.

\section{Association between allele 1 carriage and $\boldsymbol{H}$. pylori sero-positivity}

The frequency of allele 1 carriage among $H$. pylori seropositive and sero-negative subjects is presented in Table 4. Carriage of allele 1 was infrequent among $H$. pylori seropositive patients with $\mathrm{GC}$ compared to those with $\mathrm{HC}$; it was, however, comparable among patients with GC, dyspepsia, and sero-negative subjects (Table 4).

\section{Serum levels of PG-II among patients and controls}

Serum PG-II level was higher among patients with GC than $\mathrm{HC} \quad$ (mean $\pm \mathrm{SD}: \quad 17.53 \pm 12.60$ vs. $12.77 \pm 7.53$, $p=0.005$ ). However, serum PG-II levels were comparable among patients with GC than with dyspepsia and among patients with Lauren's classified types of GC (Fig. 1).

H. pylori sero-positive patients with GC had higher serum levels of PG-II than $\mathrm{HC}$, although levels were comparable among sero-negative subjects (GC/H. pylori ${ }^{+}$vs. $\mathrm{HC} / H$. pylori $^{+}: 18.78 \pm 12.63$ vs. $13.97 \pm 8.14, p=0.034$ and $\mathrm{GC} /$ H. pylori $^{-}$vs. HC/H. pylori ${ }^{-}: 15.99 \pm 12.5$ vs. $11.09 \pm 6.34$, $p=\mathrm{ns}$, respectively). However, serum PG-II was comparable among patients with GC and dyspepsia in relation to $H$. pylori infection (Fig. 1).

Serum PG-II level was similar among patients with GC than dyspepsia in relationship to IM $\left(\mathrm{GC} / \mathrm{IM}^{+}\right.$vs. dyspepsia/ 
Table 2 Genotyping patterns of PG-II polymorphism in different groups

\begin{tabular}{lcllll}
\hline Genotype pattern & GC $(n=192)$ & DC $(n=180)$ & HC $(n=240)$ & GC vs. DC $p$ value & GC vs. HC $p$ value \\
\hline $5: 1(510: 310) b p$ & $4(2.1 \%)$ & - & $5(2.1 \%)$ & - & 1.000 \\
$4: 4(480: 480) \mathrm{bp}$ & $8(4.2 \%)$ & $4(2.2 \%)$ & $3(1.3 \%)$ & 0.443 & 0.089 \\
$4: 3(480: 450) \mathrm{bp}$ & $40(20.8 \%)$ & $28(15.6 \%)$ & $32(13.3 \%)$ & 0.188 & $\mathbf{0 . 0 3 8}$ \\
$4: 2(480: 400) \mathrm{bp}$ & $21(10.9 \%)$ & $10(5.6 \%)$ & $12(5 \%)$ & 0.061 & $\mathbf{0 . 0 2 1}$ \\
$3: 3(450: 450) \mathrm{bp}$ & $20(10.4 \%)$ & $21(11.7 \%)$ & $18(7.5 \%)$ & 0.700 & 0.288 \\
$3: 2(450: 400) \mathrm{bp}$ & $21(10.9 \%)$ & $22(12.2 \%)$ & $22(9.2 \%)$ & 0.698 & 0.541 \\
$4: 1(480: 310) \mathrm{bp}$ & $29(15.1 \%)$ & $28(15.6 \%)$ & $40(16.7 \%)$ & 0.904 & 0.660 \\
$3: 1(450: 310) \mathrm{bp}$ & $27(14.1 \%)$ & $23(12.8 \%)$ & $43(17.9 \%)$ & 0.717 & 0.324 \\
$2: 1(400: 310) \mathrm{bp}$ & $6(3.1 \%)$ & $8(4.4 \%)$ & $20(8.3 \%)$ & 0.504 & 0.903 \\
$1: 1(310: 310) \mathrm{bp}$ & $16(8.3 \%)$ & $36(20 \%)$ & $45(18.7 \%)$ & $\mathbf{0 . 0 0 1}$ & $\mathbf{0 . 0 0 2}$ \\
\hline
\end{tabular}

Bold values are significant $(p<0.05)$

$G C$ gastric cancer, $D C$ dyspepsia control, $H C$ healthy control, $b p$ PCR products (in base pairs)

Statistical test: Chi-square test

Table 3 Allele 1 (310 bp) carriage distribution in different groups

\begin{tabular}{|c|c|c|c|}
\hline Allele 1 carriage vs. non-carriage & & Allele 1 (310 bp) non-carriage ${ }^{a}$ & Allele 1 (310 bp) carriage \\
\hline \multirow[t]{6}{*}{ Subject groups } & $\mathrm{GC}(n=192)$ & $110(57.3 \%)$ & $82(42.7 \%)$ \\
\hline & $\mathrm{DC}(n=180)$ & $85(47.2 \%)$ & $95(52.8 \%)$ \\
\hline & $\mathrm{HC}(n=240)$ & $87(36.3 \%)$ & $153(63.8 \%)$ \\
\hline & GC vs. DC & Reference & $0.076,0.69(0.45-1.04)$ \\
\hline & $p$ value, $\mathrm{OR}(95 \% \mathrm{CI})$ & & \\
\hline & GC vs. HC $p$ value, OR $(95 \% \mathrm{CI})$ & Reference & $<0.001,0.43(0.29-0.85)$ \\
\hline \multirow[t]{3}{*}{ Intestinal metaplasia $(\mathrm{GC}+\mathrm{DC})$} & Present $(n=79)$ & $52(65.8 \%)$ & $27(34.2 \%)$ \\
\hline & Absent $(n=265)$ & $135(50.9 \%)$ & $130(49.1 \%)$ \\
\hline & $p$ value, $\mathrm{OR}(95 \% \mathrm{CI})$ & Reference & $0.011,0.50(0.29-0.85)$ \\
\hline \multirow[t]{3}{*}{ Gastritis $(\mathrm{GC}+\mathrm{DC})$} & Present $(n=233)$ & $129(55.4 \%)$ & $104(44.6 \%)$ \\
\hline & Absent $(n=103)$ & $54(52.4 \%)$ & $49(47.9 \%)$ \\
\hline & $p$ value, $\mathrm{OR}(95 \% \mathrm{CI})$ & Reference & $0.618,0.89(0.59-1.41)$ \\
\hline \multirow[t]{3}{*}{ Lauren classification of GC } & Diffuse $(n=74)$ & $38(51.4 \%)$ & $36(48.6 \%)$ \\
\hline & Intestinal $(n=85)$ & $49(57.6 \%)$ & $36(42.4 \%)$ \\
\hline & $p$ value, $\mathrm{OR}(95 \% \mathrm{CI})$ & Reference & $0.426,1.29(0.66-2.53)$ \\
\hline
\end{tabular}

Bold values are significant $(p<0.05)$

GC gastric cancer, $D C$ dyspepsia control, $H C$ healthy control, $O R$ age- and gender-adjusted odds ratio, $95 \% C I 95 \%$ confidence interval

a Allele 1 non-carriage was taken as a reference

$\mathrm{IM}^{+}: 20.28 \pm 14.08$ vs. $19.37 \pm 15.16, p=\mathrm{ns}$ and $\mathrm{GC} /$ $\mathrm{IM}^{-}$vs. dyspepsia/IM- $17.09 \pm 12.54$ vs. $15.94 \pm 11.45$, $p=\mathrm{ns})$. Serum PG-II was also comparable in relation to gastritis (Fig. 2). However, patients with IM (GC and dyspepsia both) had higher PG-II levels than those without $(20.07 \pm 14.22$ vs. $16.61 \pm 12.08, p=0.048)$.

\section{Relationship between PG-II allele 1 carriage and serum PG-II levels}

Subjects carrying allele 1 had lower levels of PG-II than noncarriers (mean \pm SD: $14.04 \pm 9.15$ vs. $19.32 \pm 14.18$, $p<0.001)$. In case-only analysis, patients with GC carrying allele 1 also had lower PG-II levels than non-carriers (10.04 \pm 12.95 vs. $14.45 \pm 16.0, p=0.025)$ (Fig. 3).

\section{Allele 1 carriage of shorter allele and serum PG-II levels in relationship to smoking and alcohol consumption}

Allele 1 carriage and serum PG-II levels were comparable among smoker and non-smoker patients with GC (data not shown). Allele 1 carriage was also comparable, but serum PG-II level was higher among alcoholic as compared with non-alcoholic patients with GC (18.14 \pm 8.92 vs. $12.78 \pm$ 12.56, $p=0.043)$. 
Table 4 Association between PG-II allele 1 carriage and sero-positivity of Helicobacter pylori

\begin{tabular}{|c|c|c|c|c|c|c|}
\hline \multirow{2}{*}{$\begin{array}{l}\text { H. pylori sero- } \\
\text { positivity }\end{array}$} & \multicolumn{2}{|l|}{ GC } & \multicolumn{2}{|l|}{ DC } & \multicolumn{2}{|l|}{$\mathrm{HC}$} \\
\hline & $\begin{array}{l}\text { Positive } \\
(n=100)\end{array}$ & $\begin{array}{l}\text { Negative } \\
(n=68)\end{array}$ & $\begin{array}{l}\text { Positive } \\
(n=120)\end{array}$ & $\begin{array}{l}\text { Negative } \\
(n=60)\end{array}$ & $\begin{array}{l}\text { Positive } \\
(n=164)\end{array}$ & $\begin{array}{l}\text { Negative } \\
(n=76)\end{array}$ \\
\hline Non-carriers & $57(57 \%)$ & $33(48.5 \%)$ & $57(47.5 \%)$ & $28(46.7 \%)$ & $58(35.4 \%)$ & $29(38.2 \%)$ \\
\hline Allele 1 carriers & $43(43 \%)^{\mathrm{a}, \mathrm{c}}$ & $35(51.5 \%)^{\mathrm{b}, \mathrm{d}}$ & $63(52.5 \%)^{\mathrm{c}}$ & $32(53.3 \%)^{\mathrm{d}}$ & $106(64.6 \%)^{\mathrm{a}}$ & $47(61.8 \%)^{b}$ \\
\hline
\end{tabular}

$G C$ gastric cancer, $D C$ dyspepsia control, $H C$ healthy control, $O R$ age- and gender-adjusted odds ratio, $95 \%$ CI $95 \%$ confidence interval, allele 1 non-carriage was taken as a reference

GC vs. HC: ${ }^{\mathrm{a}} p=0.001, \mathrm{OR}=0.42(95 \%$ CI $0.25-0.71) ;{ }^{\mathrm{b}} p=0.169, \mathrm{OR}=0.62(0.31-1.23)$ for $H$. pylori sero-positive and sero-negative, respectively

GC vs. DC: ${ }^{\mathrm{c}} p=0.444, \mathrm{OR}=0.81(0.46-1.4) ;{ }^{\mathrm{d}} p=0.801, \mathrm{OR}=0.91(0.45-1.85)$ for $H$. pylori sero-positive and sero-negative, respectively

Fig. 1 Serum pepsinogen-II (PG-II) levels in micrograms per liter $(\mu \mathrm{g} / \mathrm{l})$ among patients and controls. a PG-II was higher among patients with gastric cancer (GC) than healthy controls (HC) but comparable to those with dyspepsia. b PG-II was similar among Lauren's classified GC. c PG-II was also higher among Helicobacter pylori sero-positive patients with GC than in HC. d PG-II was comparable among $H$. pylori sero-negative subjects. Independent $t$ test with Bonferroni's correction in subgroup analysis
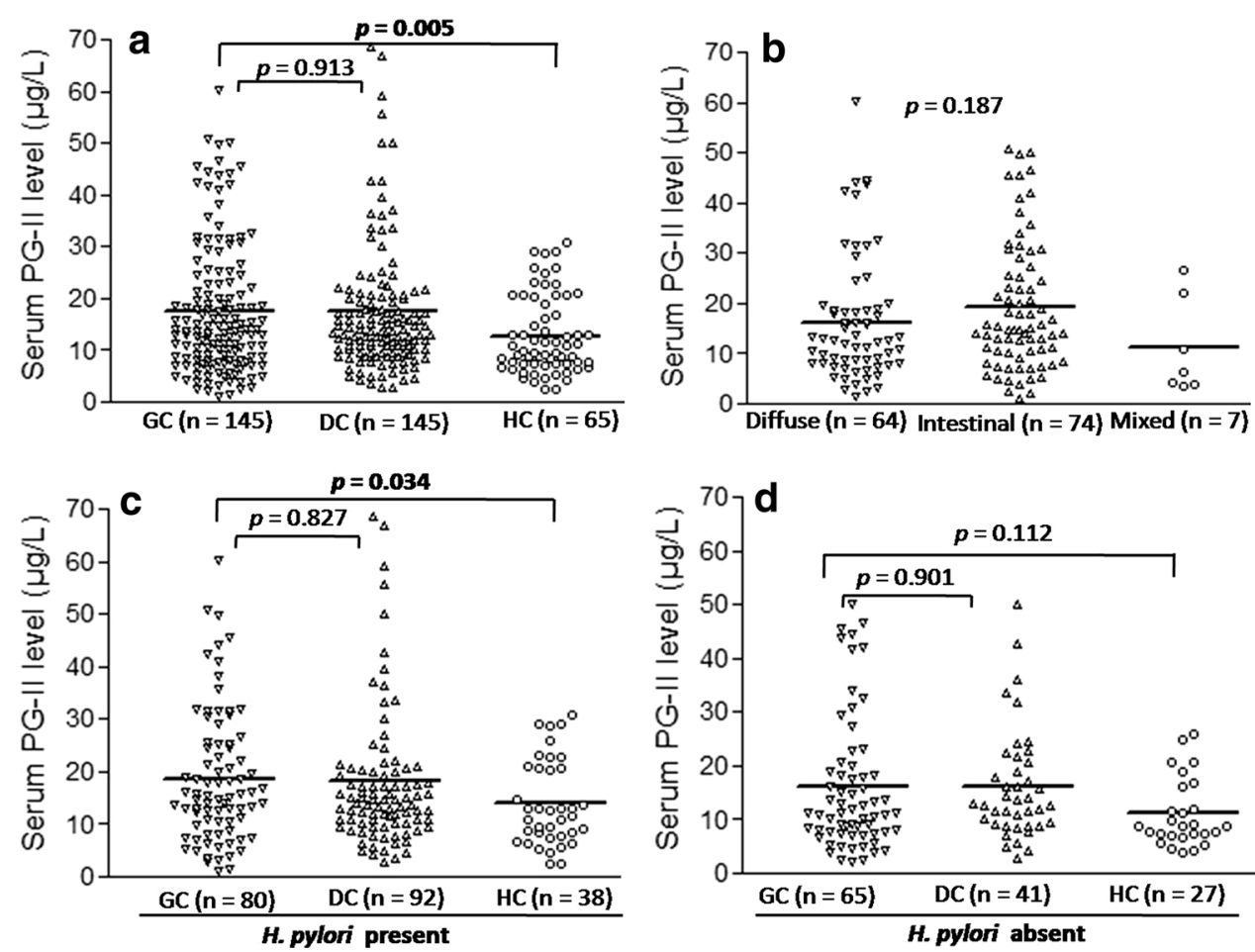

\section{Discussion}

The present study suggests a possible explanation for the low incidence of GC in India despite high rates of $H$. pylori infection in relation to IM and gastritis as follows. (1) Allele 1 carriage was infrequent and serum PG-II level was higher among patients with $\mathrm{GC}$ compared to $\mathrm{HC}$ alone and in the presence of $H$. pylori, (2) patients with IM (GC and dyspepsia both) also had infrequent allele 1 carriage and higher PG-II level than those without, (3) however, allele 1 carriage and serum PG-II level were comparable among patients with intestinal or diffuse type of GC and among patients with gastritis compared to those without.

Although the PG-II $100 \mathrm{bp}$ ins/del polymorphism has been thought to be a risk factor for GC, only three studies on this issue have been reported till date. Of these, two studies were from Asia (one from China and the other from Japan) and one from Portugal [6-8]. Although the Asian studies suggested that allele 1 carrier of this polymorphism was a risk factor for GC, the study from Portugal found it to be a protective factor. Such contradictory observations might be related to the racial and genetic differences in different populations. However, statistical error resulting from inadequate sample size and differences in frequency of $H$. pylori infection may also be an explanation for this discordance. Surprisingly, evaluation for $H$. pylori infection, GC, and this polymorphism was not done in these studies. As $H$. pylori infection causes inflammation in the gastric mucosa and duodenum, we have included patients with dyspepsia as a disease control group for evaluation of 
Fig. 2 Serum PG-II levels in micrograms per liter $(\mu \mathrm{g} / \mathrm{l})$ among patients. a PG-II was $\mathrm{GC}$ and dyspepsia in relation to intestinal metaplasia (IM). b However, PG-II was higher among patients with IM (GC and dyspepsia both) than in those without. c PG-II was comparable in relation to gastritis, and among patients with gastritis (GC and dyspepsia both) than those without (d) comparable among patients with
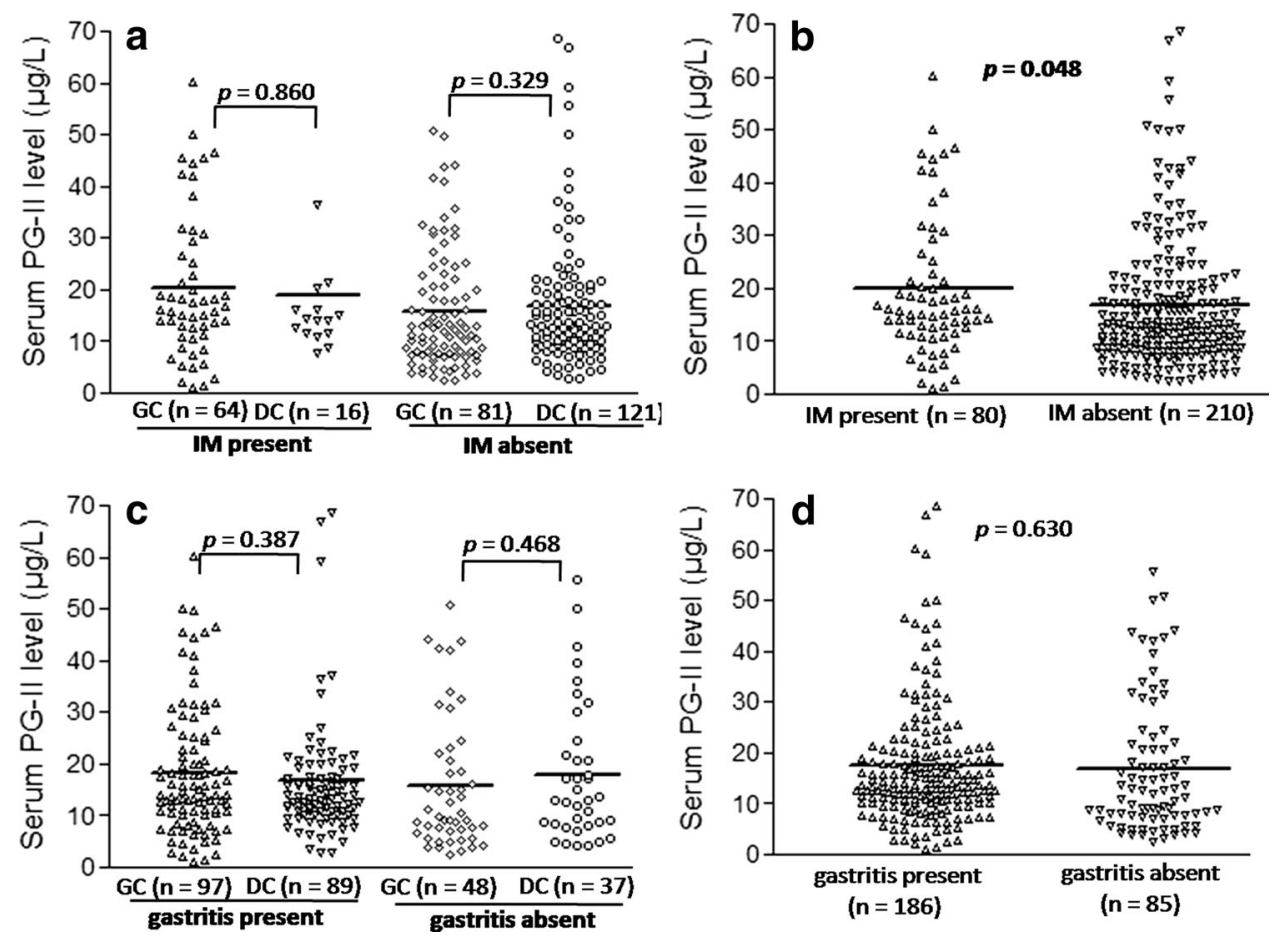

Fig. 3 Serum PG-II levels among all subjects (a) and in patients with GC only (b). An independent $t$ test was used to compare PG-II levels among allele 1 carriers and non-carriers
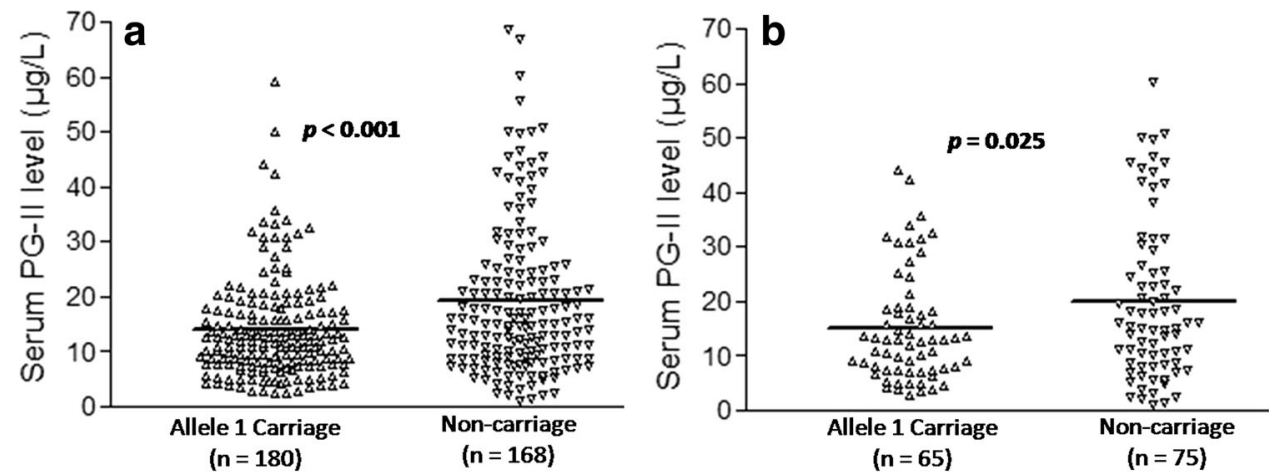

H. pylori-associated precancerous lesions, e.g., gastritis and IM [28, 29]. Accordingly, in the current case-control study in which sample size was calculated statistically, we investigated the relationship between genetic polymorphism in the PG-II gene and GC in relationship to $H$. pylori infection in a northern Indian population.

Moreover, in India, in spite of the high frequency of $H$. pylori infection, the frequency of GC is quite low (this is known as the Indian enigma). A similar enigma has been described from Africa, Malaysia, Colombia, and Costa Rica [30-33]. All previous studies on the relationship between genetic polymorphism in the PG-II gene and GC were undertaken in populations with high risk for GC. Ours is perhaps the first study on the relationship between genetic polymorphism in the PG-II gene and GC in a population with low risk for GC. Only a single study from southern India has evaluated the frequency of pepsinogen phenotypes among patients with duodenal ulcer [34]. We have found that genotype frequency among patients with GC was different compared to dyspepsia and HC. The carriage of allele 1 (310 bp) is important in the genotype of the PG-II $100 \mathrm{bp}$ ins/del polymorphism [6, 7, 35]. Interestingly, our study revealed that carriage of allele 1 was frequent in our healthy population $(63.8 \%)$. The results of a Chinese study (57.1-61.0\%) and a Portuguese study (72.4\%) were similar to our observation [7]. However, another Asian study (Japanese: $46.3 \%$ ) showed discordance with our findings $[6,36]$. We also found that carriage of allele 1 (310 bp, the shorter allele) was infrequent among patients with GC compared to HC. Although the results of our study are in accordance with the Portugal study, these are in contradiction to the results of studies from China and Japan, which are high-risk areas for GC. Hence, the current study may offer an explanation for the 
Indian enigma of low frequency of GC in spite of a high rate of $H$. pylori infection.

Precancerous lesions such as IM and gastritis increase the susceptibility for development of GC. In our study, the frequency of allele 1 carriage was comparable among patients with GC and dyspepsia in presence or absence of IM and gastritis. However, allele 1 carriage was protective against the development of IM. This result was also supported by a Portuguese study (OR 0.28; $95 \%$ CI, $0.14-0.59$ ) [7]. We found that allele 1 carriage was comparable among patients with or without gastritis and with different types of GC using the Lauren classification. However, one Chinese study showed that the homozygous allele 1 was infrequent among patients with superficial gastritis $(7.83 \%)$ compared to $\mathrm{AG}(18.0 \%)$ and $\mathrm{GC}$ $(20.2 \%)$ [35]. In general, the prevalence of $A G$ and GC is low in India, particularly in the northern part of India, which might be an explanation for this observation.

The role of $H$. pylori in gastric carcinogenesis varies according to the background of populations. In this study, we examined the association between the genetic polymorphism of PG-II with its serum levels and GC in relation to $H$. pylori infection. We observed that allele 1 carriage was infrequent among patients with GC who were seropositive for H. pylori. However, a previous Japanese casecontrol study showed no differences in allelic frequency of PG-II polymorphisms among patients with gastric body ulcer in the presence and absence of $H$. pylori infection [36]. H. pylori colonizes in the stomach mucosa and increases the risk of $\mathrm{GC}$, being closely related to the level of serum PGs. Thus, it is quite natural that $H$. pylori affects the level of PG-II. We also found that patients with $H$. pylori sero-positive GC had higher PG-II levels than $\mathrm{HC}$, but data were comparable in sero-negative subjects. These observations suggest that the presence of $H$. pylori and allele 1 carriage alter the level of PG-II, and perhaps have a key role in the protection against GC but not gastric ulcer. Furthermore, two other studies from our center suggested other explanations for this paradox [37-39].

Correa's hypothesis suggests that intestinal and diffuse types of GC may have different pathogenesis because of their different epidemiological features [40]. Serum PG levels were found to be different in intestinal and diffuse types of GC, which are probably related to the severity of AG and IM according to histological type. Patients with GC had higher PG-II levels than HC in our study. A similar study showing increase in PG-II level in GC has been reported earlier [19]. We also found that patients with IM (GC and dyspepsia both) had higher PG-II levels than those without. However, low sensitivity and specificity for cutoff of PG-II levels suggest that this test is not useful for detection of GC and IM. Furthermore, serum PG-II level was comparable among patients with GC and dyspepsia as well as among patients with intestinal and diffuse type of GC. Low frequency of AG in patients with intestinal type of GC in our population and possible type II statistical error may be explanations for this observation [41, 42].

Subjects with allele 1 carriage had lower levels of serum PG-II. Patients with GC having allele 1 also had lower PGII levels than those without. Previous analysis of the genomic sequence consisting of the $100 \mathrm{bp}$ ins/del polymorphism (Genome USCS NM_002630; Ref. NM_002630.1) suggests that an extensive number of TATA-box sequences (responsible for active gene expression) was present between exons 7 and 8 , altering the level of PG-II [43]. These observations suggest that allele 1 (310 bp) is a deletion fragment of the PG-II $100 \mathrm{bp}$ ins/del gene polymorphism and acts as an under-producer of PGII, whereas allele 2 (400 bp), allele 3 (450 bp), allele 4 (480 bp), and allele 5 (510 bp) had insertion fragments and were over-producers. Our study showing frequent presence of shorter allele (allele 1) is associated with protection against the development of GC in the Indian population.

In conclusion, the present study shows that allele 1 carriage (310 bp) of the PG-II $100 \mathrm{bp}$ ins/del polymorphism is infrequent; however, circulating PG-II level is elevated among patients with GC, particularly those having $H$. pylori infection and IM. Higher frequency of the shorter allele (under-producer of serum PG-II) in our healthy population might be an explanation for lower prevalence of $\mathrm{GC}$ in the Indian enigma.

Acknowledgments U.C.G. thanks the Indian Council of Medical Research, New Delhi, India for financial support under the project No. 5/4/3-1/2007-NCD-II. S.K. thanks the University Grant Commission, New Delhi for providing the fellowship (F. No. 10-2(5)/2007(ii)E.U.II).

Compliance with ethical standards

Conflict of interest None.

\section{References}

1. Parkin DM, Bray F, Ferlay J, Pisani P. Estimating the world cancer burden: Globocan 2000. Int J Cancer. 2001;94:153-6.

2. Dikshit R, Gupta PC, Ramasundarahettige C, et al. Cancer mortality in India: a nationally representative survey. Lancet. 2012;379:1807-16.

3. Correa P. Human gastric carcinogenesis: a multistep and multifactorial process-First American Cancer Society Award Lecture on Cancer Epidemiology and Prevention. Cancer Res. 1992;52:6735-40.

4. Taggart RT, Boudi FB, Bell GI. RFLPs for the human pepsinogen A haplotypes (PGA). Nucleic Acids Res. 1988;16:9371.

5. Taggart RT, Azuma T, Wu S, Bell GI, Bowcock AM. A highly informative polymorphism of the pepsinogen $\mathrm{C}$ gene detected by polymerase chain reaction. Adv Exp Med Biol. 1991;306:95-9. 
6. Liu HJ, Guo XL, Dong M, Wang L, Yuan Y. Association between pepsinogen $\mathrm{C}$ gene polymorphism and genetic predisposition to gastric cancer. World J Gastroenterol. 2003;9:50-3.

7. Pinto-Correia AL, Sousa H, Fragoso M, et al. Gastric cancer in a Caucasian population: role of pepsinogen $\mathrm{C}$ genetic variants. World J Gastroenterol. 2006;12:5033-6.

8. Yamagata Z, Zhang Y, Shinozaki S, et al. Influence of pepsinogen gene polymorphisms on serum pepsinogen. Ann Hum Genet. 1997;61:93-7.

9. Samloff IM, Liebman WM. Cellular localization of the group II pepsinogens in human stomach and duodenum by immunofluorescence. Gastroenterology. 1973;65:36-42.

10. Storskrubb T, Aro P, Ronkainen J, et al. Serum biomarkers provide an accurate method for diagnosis of atrophic gastritis in a general population: the Kalixanda study. Scand J Gastroenterol. 2008;43:1448-55.

11. Correa P. Serum pepsinogens in gastric cancer screening. Dig Dis Sci. 2010;55:2123-5.

12. Dinis-Ribeiro M, da Costa-Pereira A, Lopes C, et al. Validity of serum pepsinogen I/II ratio for the diagnosis of gastric epithelial dysplasia and intestinal metaplasia during the follow-up of patients at risk for intestinal-type gastric adenocarcinoma. Neoplasia. 2004;6:449-56.

13. di Mario F, Cavallaro LG. Non-invasive tests in gastric diseases. Dig Liver Dis. 2008;40:523-30.

14. Leung WK, Wu MS, Kakugawa Y, et al. Screening for gastric cancer in Asia: current evidence and practice. Lancet Oncol. 2008;9:279-87.

15. Miki K, Morita M, Sasajima M, et al. Usefulness of gastric cancer screening using the serum pepsinogen test method. Am J Gastroenterol. 2003;98:735-9.

16. Samloff IM, Stemmermann GN, Heilbrun LK, Nomura A. Elevated serum pepsinogen I and II levels differ as risk factors for duodenal ulcer and gastric ulcer. Gastroenterology. 1986;90:570-6.

17. Dinis-Ribeiro M, Areia M, de Vries AC, et al. Management of precancerous conditions and lesions in the stomach (MAPS): guideline from the European Society of Gastrointestinal Endoscopy (ESGE), European Helicobacter Study Group (EHSG), European Society of Pathology (ESP), and the Sociedade Portuguesa de Endoscopia Digestiva (SPED). Virchows Arch. 2012;460:19-46.

18. Kishi K, Kinoshita Y, Matsushima Y, et al. Pepsinogen C gene product is a possible growth factor during gastric mucosal healing. Biochem Biophys Res Commun. 1997;238:17-20.

19. Kitahara F, Kobayashi K, Sato T, et al. Accuracy of screening for gastric cancer using serum pepsinogen concentrations. Gut. 1999;44:693-7.

20. Miwa H, Ghoshal UC, Gonlachanvit S, et al. Asian consensus report on functional dyspepsia. J Neurogastroenterol Motil. 2012;18:150-68.

21. Suzuki H, Moayyedi P. Helicobacter pylori infection in functional dyspepsia. Nat Rev Gastroenterol Hepatol. 2013;10:168-74.

22. Tack J, Talley NJ, Camilleri M, et al. Functional gastroduodenal disorders. In: Drossman D, editor. Rome III: the functional gastrointestinal disorders. 3rd ed. McLean, VA: Degnon Associates; 2006. p. 419-86.

23. Lauren $\mathrm{P}$. The two histological main types of gastric carcinoma: diffuse and so-called intestinal-type carcinoma. An attempt at a histo-clinical classification. Acta Pathol Microbiol Scand. 1965;64:31-49.

24. Dixon MF, Genta RM, Yardley JH, Correa P. Classification and grading of gastritis. the updated Sydney system. International Workshop on the Histopathology of Gastritis, Houston 1994. Am J Surg Pathol. 1996;20:1161-81.

25. Correa P. Chronic gastritis: a clinico-pathological classification. Am J Gastroenterol. 1988;83:504-9.
26. Ghoshal UC, Kumar S, Krishnani N, et al. Serological assessment of gastric intestinal metaplasia and atrophy using pepsinogen-I, pepsinogen-II and gastrin-17 levels in a low incidence area of gastric cancer endemic for $H$. pylori infection. Trop Gastroenterol. 2011;32:292-8.

27. Ghoshal UC, Ghosh TK, Ghoshal U, et al. In-house rapid urease test kit and commercial kit: which is better? Indian J Gastroenterol. 1999;18:183.

28. Suzuki H, Nishizawa T, Hibi T. Can Helicobacter pylori-associated dyspepsia be categorized as functional dyspepsia? J Gastroenterol Hepatol. 2011;26(suppl 3):42-5.

29. Suzuki H, Matsuzaki J, Hibi T. What is the difference between Helicobacter pylori-associated dyspepsia and functional dyspepsia? J Neurogastroenterol Motil. 2011;17:124-30.

30. Bravo LE, van Doom LJ, Realpe JL, Correa P. Virulence-associated genotypes of Helicobacter pylori: do they explain the African enigma? Am J Gastroenterol. 2002;97:2839-42.

31. Goh KL, Cheah PL, Md N, Quek KF, Parasakthi N. Ethnicity and H. pylori as risk factors for gastric cancer in Malaysia: a prospective case control study. Am J Gastroenterol. 2007;102: $40-5$.

32. Con SA, Valerin AL, Takeuchi $\mathrm{H}$, et al. Helicobacter pylori CagA status associated with gastric cancer incidence rate variability in Costa Rican regions. J Gastroenterol. 2006;41:632-7.

33. Ghoshal UC, Chaturvedi R, Correa P. The enigma of Helicobacter pylori infection and gastric cancer. Indian J Gastroenterol. 2010;29:95-100.

34. Venkateshwari A, Vidyasagar A, Prasad R, Pratap B, Pratibha N. Pepsinogen polymorphism in the Indian population and its association with duodenal ulcer. Hum Genet. 1997;101:201-4.

35. Sun LP, Gong YH, Dong NN, Wang L, Yuan Y. Correlation of pepsinogen $\mathrm{C}$ (PGC) gene insertion/deletion polymorphism to PGC protein expression in gastric mucosa and serum. Ai Zheng. 2009;28:487-92.

36. Ohtaka Y, Azuma T, Konishi J, Ito S, Kuriyama M. Association between genetic polymorphism of the pepsinogen $\mathrm{C}$ gene and gastric body ulcer: the genetic predisposition is not associated with Helicobacter pylori infection. Gut. 1997;41:469-74.

37. Tripathi S, Ghoshal U, Mittal B, et al. Association between gastric mucosal glutathione- $S$-transferase activity, glutathione- $S$ transferase gene polymorphisms and Helicobacter pylori infection in gastric cancer. Indian J Gastroenterol. 2011;30:257-63.

38. Ghoshal U, Kumar S, Jaiswal V, et al. Association of microsomal epoxide hydrolase exon 3 Tyr113His and exon 4 His139Arg polymorphisms with gastric cancer in India. Indian J Gastroenterol. 2013;32:246-52.

39. Ghoshal U, Tripathi S, Kumar S, et al. Genetic polymorphism of cytochrome P450 (CYP) 1A1, CYP1A2, and CYP2E1 genes modulate susceptibility to gastric cancer in patients with Helicobacter pylori infection. Gastric Cancer. 2014;17:226-34.

40. Correa P, Schneider BG. Etiology of gastric cancer: what is new? Cancer Epidemiol Biomarkers Prev. 2005;14:1865-8.

41. Ghoshal UC, Tiwari S, Dhingra S, et al. Frequency of Helicobacter pylori and CagA antibody in patients with gastric neoplasms and controls: the Indian enigma. Dig Dis Sci. 2008;53:1215-22.

42. Ghoshal UC, Tripathi S, Ghoshal U. The Indian enigma of frequent $H$. pylori infection but infrequent gastric cancer: is the magic key in Indian diet, host's genetic makeup, or friendly bug? Am J Gastroenterol. 2007;102:2113-4.

43. Pals G, Azuma T, Mohandas TK, et al. Human pepsinogen C (progastricsin) polymorphism: evidence for a single locus located at 6p21.1-pter. Genomics. 1989;4:137-48. 